\title{
Article
}

\section{Toxicity Testing by the Microbial Assay for Risk Assessment (MARA) in Relation to Trace Elements Content in King Bolete (Boletus edulis) Collected in Several Sites of Poland}

\author{
Muhamad Alfiyan Zubaidi ${ }^{1}$, Jędrzej Proch ${ }^{2}$ (D), Piotr Konieczny ${ }^{1, *}$ and Łukasz Tomczyk ${ }^{1}$ (D) \\ 1 Department of Food Quality and Safety Management, Faculty of Food Science and Nutrition, \\ Poznan University of Life Sciences, Wojska Polskiego 31, 60-624 Poznań, Poland; \\ alfiyan1994@gmail.com (M.A.Z.); tomczyk@up.poznan.pl (Ł.T.) \\ 2 Department of Analytical Chemistry, Faculty of Chemistry, Adam Mickiewicz University in Poznań, \\ Uniwersytetu Poznańskiego 8, 61-614 Poznań, Poland; jedrzej.proch@amu.edu.pl \\ * Correspondence: piotr.konieczny@up.poznan.pl
}

check for updates

Citation: Zubaidi, M.A.; Proch, J.; Konieczny, P.; Tomczyk, Ł. Toxicity Testing by the Microbial Assay for Risk Assessment (MARA) in Relation to Trace Elements Content in King Bolete (Boletus edulis) Collected in Several Sites of Poland. Appl. Sci. 2021, 11, 4166. https://doi.org/ 10.3390/app11094166

Academic Editors: Marco Iammarino, Carmen Palermo and Igor Tomasevic

Received: 23 March 2021

Accepted: 30 April 2021

Published: 2 May 2021

Publisher's Note: MDPI stays neutral with regard to jurisdictional claims in published maps and institutional affiliations.

Copyright: (C) 2021 by the authors. Licensee MDPI, Basel, Switzerland. This article is an open access article distributed under the terms and conditions of the Creative Commons Attribution (CC BY) license (https:// creativecommons.org/licenses/by/ $4.0 /)$.
Abstract: Boletus edulis (King bolete) is one of the most consumed wild mushrooms on a global scale, but this is particularly the case in Poland. Several studies have reported that mushrooms accumulate many potentially toxic elements (PTEs) such as $\mathrm{Hg}, \mathrm{Pb}$, and $\mathrm{Cd}$, which may lead to adverse effects. Therefore, in this preliminary study, an assessment of the potential of a microbial assay for risk assessment (MARA) for ecotoxicological testing of both dried samples of fruiting bodies of King bolete collected from several sites of Poland and water extracts of mushrooms being tested were analyzed. An evaluation of MARA response in Boletus edulis extracts was performed to identify their toxicity and then, using the same samples, instrumental determination of 10 elements ( $\mathrm{Al}, \mathrm{As}, \mathrm{Cd}$, $\mathrm{Cr}, \mathrm{Cu}, \mathrm{Fe}, \mathrm{Hg}, \mathrm{Ni}, \mathrm{Pb}$, and $\mathrm{Zn}$ ) was performed. In general, the MARA responses indicated that the samples were only slightly toxic or nontoxic. Similarly, most of the PTEs were not detected in all dried samples of the fruiting bodies of King bolete. However, the analysis of digested samples (total content) proved that the elements' content in water extracts was markedly lower than in dried fruit bodies. It implies that the MARA test corresponded better to the elements that are well extracted in water. Therefore, the MARA system can be applied for toxic identification if the targeted toxin is highly extracted in water. Further and more detailed research is still needed to develop reliable approach in order to evaluate the ecotoxicity in food-related bio-based raw materials using the MARA assay.

Keywords: microbial assay; mushrooms extracts; risk assessment; bioaccumulation; exposure

\section{Introduction}

Mushrooms are a nutritious food that have many health benefits. Their nutrients, such as polysaccharides and antioxidants, are beneficial for bowel function, preventing hypertension, and improving the immune system. Additionally, mushrooms are relatively rich in nutritionally essential bio-metals such as $\mathrm{Zn}, \mathrm{Cu}, \mathrm{Mn}$, and Se [1]. On the other hand, mushrooms are a tasty food appreciated by many people, which is evidenced by high consumption, particularly of wild mushrooms in Eastern Europe and Asia [2].

Wild mushrooms are believed to be more nutritious and tastier than cultivated ones. Consequently, the demand for wild edible mushrooms has soared continuously across the globe, though mainly in Europe and Asia. Furthermore, wild mushrooms have therapeutic effects, which are useful in preventing many health issues due to their antibacterial, antimutagenic, and antiviral activities. In fact, Poland is Europe's largest producer and exporter of wild and edible mushrooms, with more than 2.38 million $\mathrm{kg}$ of mushrooms produced annually [3].

On the other hand, wild mushrooms are prone to be more poisonous since they grow in an uncontrolled environment in which pollutants may be accumulated in the mushroom. 
In addition, some poisonous mushroom species mimic the appearance of non-poisonous ones, which leads to unintentional picking. Consequently, mushroom poisoning is an inevitable occurrence that must be faced [4].

The food industry has started to produce wild mushrooms or repack them from local mushroom pickers. Therefore, safety assurance is one of the primary challenges facing the industry. In comparison to fruits and vegetables, mushrooms are known to accumulate more heavy metals [5]. Boletus edulis is one of the species that has been widely reported to contain a high amount of toxic elements such as $\mathrm{Cd}, \mathrm{Pb}$, and $\mathrm{Hg}$, with concentrations of up to 20,3 , and $5 \mathrm{mg} \mathrm{kg}^{-1} \mathrm{DM}$ (dry matter), respectively [6]. On the one hand, Boletus edulis is the most common mushroom collected and consumed in Poland. On the other hand, the genus Boletus has been identified as an accumulator of metals [7].

The European Union sets standards for the maximum permissible concentration of cadmium and leads in mushrooms, including Boletus edulis, at $1 \mathrm{mg} \mathrm{kg}^{-1}$ and $0.3 \mathrm{mg} \mathrm{kg}^{-1}$, respectively [8]. Therefore, Falandysz et al. [6] found a toxic element that exceeded the maximum value for posing a health risk to consumers. In view of the fact that the consumption of mushrooms in Poland is relatively high, studies to evaluate mushrooms' toxicity are extremely demanding. Recently, mushroom toxicity can be determined by either heavy metal or biotoxin assay. However, those methods require several types of assay, which consume a great deal of time and money.

In the last two decades, environmental controls and research using bio indicative methods have been used in many countries of Europe and around the world. Due to the current practice of biotest applications in modern ecotoxicology, the main objects of ecotoxicological studies are toxic ingredients present in the five main environments such as air, soil, terrestrial, water (incl. sediments), and the responses of selected macro-biological systems in nature. Different toxicants are involved in the research, like organic, inorganic or organic-mineral, and natural (biotic or abiotic) and artificial, mostly anthropogenic origin [9]. In recent years, there has been intense development in bioanalytical techniques that employ live organisms as indicators [10]. Behind conventional chemical and mostly instrumentally advanced techniques, numerous ecotoxicological biotests are employed for assessing the impact of pollutants on live organisms from chemicals and environmental samples. Commonly available toxicity bioassays for ecological risk assessment use living cells, tissues, organisms, or communities like bacteria and fungi, plants, terrestrial invertebrates, and terrestrial vertebrates [11].

Microbial Assay for Risk Assessment (MARA) is a patented system that can evaluate ecotoxicity in a single run in an array of 11 genetically diverse test microorganisms. The microorganisms used in the MARA system have different responses to a wide variety of toxic compounds [12,13]. Selected microorganisms representing 10 prokaryotic species and one eukaryote (yeast) can be exposed to any chemical or environmental sample in different dilutions. MARA was implemented in several applications; chemical toxicity (acrylamide, hydrogen peroxide, and phenol) [12], environmental samples (waters, effluents, sewage sludges, and soil leachates) [14], cesium toxicity [15], antibiotics toxicity [16], and cyanobacterial toxicity [13]. However, the system has not been widely used to determine toxicity in food products or food-related raw materials. Therefore, the principal aim of this preliminary study was to validate whether the MARA is applicable to evaluate the ecotoxicity of some selected wild-growing mushrooms. The response of microorganisms used in the assay will also be determined with regard to the presence or absence of certain trace elements in water-based extracts of King bolete (Boletus edulis) samples.

\section{Materials and Methods}

\subsection{Materials}

The mushrooms analyzed (Boletus edulis) came from forests located in 6 regions of Poland: 1. Near Warsaw (individually picked and dried), 2. Powidz village, Greater Poland (also individually picked and dried), 3. Near Gdańsk, 4. Near Kraków (collected in 2020), 
5. Near Kraków (collected in 2019), 6. Near Góra town, Lower Silesia. The map of samples collected is shown in Figure 1.

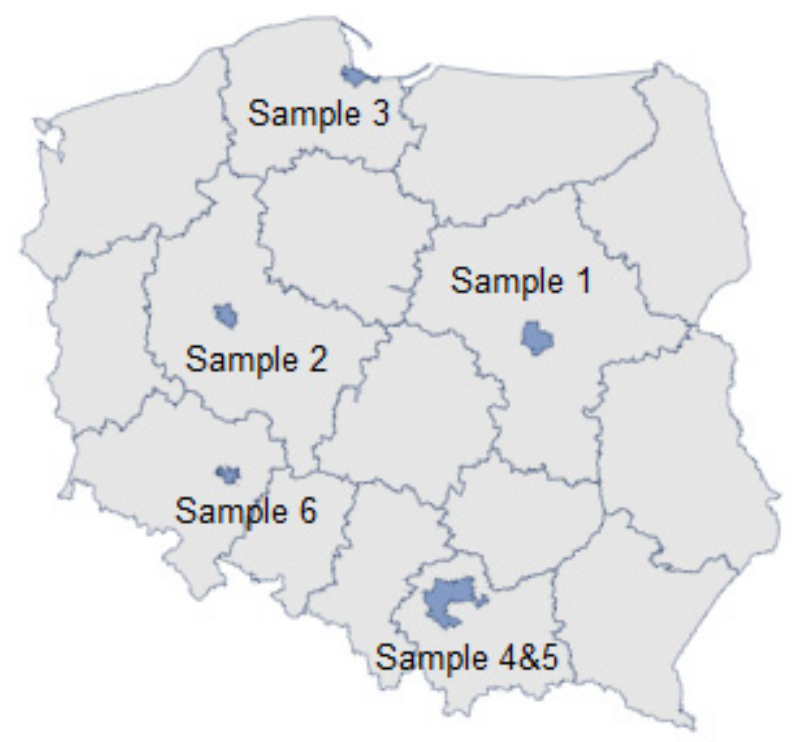

Figure 1. Sampling location map.

Samples of mushrooms were picked fresh in the forest and dried using a home oven (Samples 1 and 2) or purchased in a dried form on the market from local producers offering packages between 20 and $30 \mathrm{~g}$ (Samples 3-6). All suppliers assured that mushrooms were collected in nearby forests. The 1st site was located in central Poland, close to Kampinos village and about $50 \mathrm{~km}$ from Poland's capital Warsaw, a city with approximately 1,800,000 inhabitants. The 2nd sampling site was located in the village of Powidz (Great Poland province), situated far away from industrial pollution sources and a very popular site for mushroom picking among the local inhabitants. The sampling sites 3 and 6 represented popular places for summer vacations and tourist activity. In September, October, and November, these regions were filled with milk caps, porcini, bay bolete, and many other edible, common mushrooms, which were either eaten fresh, dried, or frozen at home, given to family members, or sold at markets and even by the roadsides. Samples 4 and 5 were collected in the south of Poland, close to Kraków, in a region with an enormous concentration of industry, mainly hard coal mining, electric power industry, and transportation.

The reagents used in the element measurement were high-pure argon (N-5.0, purity $99.999 \%$ ), obtained from Linde (Kraków, Poland), which was employed as plasma gas. $65 \%$ nitric acid was obtained from Merck ICP. Commercial analytical standards (Romil, Cambridge, UK) were used for calibration. All reagents were diluted by high-pure deionized water ( $\geq 18 \mathrm{M} \Omega \mathrm{cm}$ resistivity) obtained from Milli-Q water purification system (Merck Millipore, Darmstadt, Germany). The materials used in the MARA were phytone peptone and tetrazolium red (TZR), MARA plate, and its software, which were bought from Tigret (Warsaw, Poland) as the local, official supplier of the assay.

\subsection{Microbial Assay for Risk Assessment (MARA)}

MARA (Microbial Assay for Risk Assessment) was a $24 \mathrm{~h}$ multi-species assay used to measure ecotoxicity from chemical and environmental samples. Taxonomically diverse microbial species used in the test were lyophilized on a microplate. The microbes consisted of 10 prokaryotic species and a eukaryote (yeasts). The details of the microorganisms used were shown in Table 1 [15]. In the assay, the microorganisms were exposed to a dilution series of the samples, and the growth of the microorganisms was determined with the reduction of tetrazolium red (TZR) [14]. 
Table 1. Microorganism applied in MARA.

\begin{tabular}{ccc}
\hline Strain No. & Microbial Name & Characteristics \\
\hline S1 & Microbacterium species & Gram (+) \\
S2 & Brevundimonas diminuta & Gram (-) \\
S3 & Citrobacter freundii & Gram (-) \\
S4 & Comamonas testosteroni & Gram (-) \\
S5 & Enterococcus casseliflavus & Gram (-) \\
S6 & Delftia acidovorans & Gram (+) \\
S7 & Kurthia gibsonii & Gram (+) \\
S8 & Staphylococcus warneri & Gram (-) \\
S9 & Pseudomonas aurantiaca & Gram (-) \\
S10 & Serratia rubidaea & Yeast \\
S11 & Pichia anomalia &
\end{tabular}

The characteristics of the microorganism used in the MARA assay were as follows:

1. Microbacterium species is a Gram-positive bacterium that has thermoduric, saprophytic, and nonmotile properties. It is widely found in both the dairy and the gastrointestinal tract [17];

2. Breoundimonas diminuta is a Gram-negative bacterium used as a marker in the efficiency of a water filter [18];

3. Citrobacter freundii is a facultative anaerobic Gram-negative bacterium that is widely found in the environment, food, and gastrointestinal tract. It is also known as a pathogen that causes health issues in the respiratory and urinary tract. However, it is beneficial in the bioremediation of copper [19];

4. Comamonas testosteroni is an aerobic Gram-negative bacterium that is widely found in the soil. It is found in a very polluted environment [20];

5. Enterococcus casseliflavus is a Gram-positive bacterium with a resistance to high temperatures up to $60^{\circ} \mathrm{C}$ [21];

6. Delftia acidovorans is a Gram-negative bacterium that is widely found in soil in water. It is known as gold nuggets due to its ability to dissolve gold into nanoparticles [22];

7. Kurthia gibsonii is a Gram-positive bacterium that is commonly found in any environment contaminated with animal feces [23];

8. Staphylococcus warneri is a Gram-positive bacterium that is generally found in human and animal skins. It is a commensal organism, which can rarely cause diseases, but in immunocompromised patients with invasive treatments or medical device implants may cause sepsis and endocarditis [24];

9. Pseudomonas aurantiaca is a Gram-negative microorganism commonly found in soils [25];

10. Serratia rubidaea is a Gram-negative bacterium that is likely found in water and soils [26];

11. Pichia anomalia is a yeast widely found in industrial sewages, soils, grains, and sweet water [13].

A scanned image of the microplate obtained using a flatbed scanner was analyzed using purpose-built software. The system framework is briefly illustrated in Figure 2 [14].

\subsubsection{Sample Preparation}

An aqueous extract (10:1) was prepared by soaking each mushroom cap in distilled water for $12 \mathrm{~h}$ at $20^{\circ} \mathrm{C}$. After soaking, the sample was centrifuged at $3000 \mathrm{rpm}$ for $15 \mathrm{~min}$ to remove particulate matter. A total of $20 \mathrm{~mL}$ of supernatant was collected using a syringe of $0.45 \mu \mathrm{m}$. Then $0.4 \mathrm{~g}$ of phytone peptone was dissolved in the sample, and $200 \mu \mathrm{L}$ of tetrazolium red (TZR) was added. The prepared samples were analyzed immediately after preparation. Aqueous extracts were determined parallel by ICP-HROES (see the Section 2.3 Total element content measurements). 


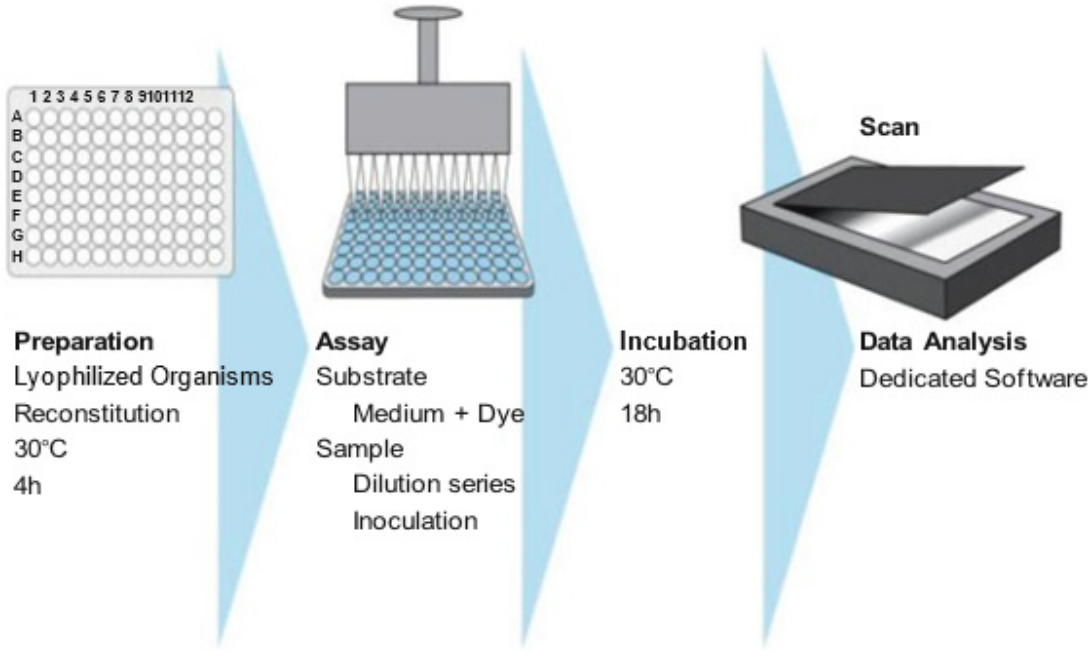

Figure 2. MARA framework.

\subsubsection{Plate Preparation}

The plate's temperature was equilibrated (for $2 \mathrm{~h}$ ) to room temperature after removal from their protective packaging. A volume of $150 \mu \mathrm{L}$ of medium (phytone peptone, $2 \% w / v$ ) was transferred to each well in row $\mathrm{H}$ (Rows H, columns 1 to 12) (Figure 3). Columns 1 to 11 contained the microorganisms, and column 12 contained only a cryoprotectant agent used as contamination control. After the medium was added, the plates were incubated at $30{ }^{\circ} \mathrm{C}$ for $4 \mathrm{~h}$ to re-activate the microorganisms [14].

ROWS

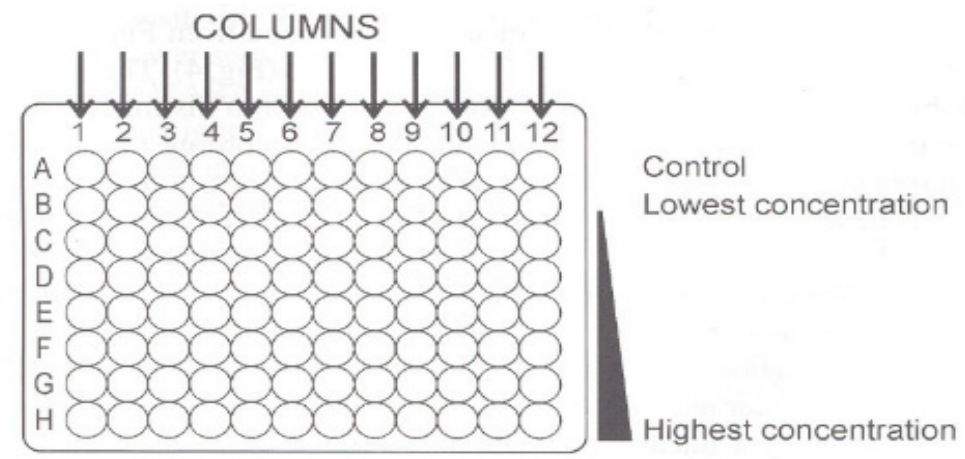

Figure 3. MARA 96-well microplate.

\subsubsection{Inoculation and Incubation}

Inoculation of the microorganism was performed by transferring $15 \mu \mathrm{L}$ of the suspension from row $\mathrm{H}$ to each well starting from row $\mathrm{A}$ to row $\mathrm{G}$. Consequently, each well was inoculated with the same amount of bacterial suspension. Lastly, the plates were sent to an incubator, set at $30^{\circ} \mathrm{C}$ and incubated for $18 \mathrm{~h}$.

\subsubsection{Test Measurement}

The measurement was conducted after incubation. The plates were cleaned from any condensation using tissue paper carefully without shaking the plates. The lid was removed before measurement using a transmitted light scanner. The scanned image was analyzed using MARA software, specially designed software to perform sample toxicity analysis.

\subsubsection{MARA Toxicity Determination}

The data obtained from MARA can be expressed as the percentage of microbial growth, the percentage of relative inhibition, and microbial toxicity concentration (MTC). MTC is also known as a unique fingerprint and it is the most informative result to determine 
the toxicity of each individual sample [13]. MTC value indicates the sample concentration needed to be recognized as toxic. Consequently, the higher the MTC values, the less toxic the sample [14]. The MTC value was determined as follow:

$$
\mathrm{MTC}=\mathrm{c}_{\min } \times \mathrm{d}^{(\mathrm{Ptot} / \mathrm{Po})-1}
$$

where:

$c_{\min }$ : Lowest concentration in the gradient

Po: Pellet size in the control

d: Dilution factor

Ptot: Sum of all pellet sizes across the concentration gradient

\subsection{Total Element Content Measurements}

\subsubsection{Microwave-Assisted Wet Digestion}

The microwave-assisted wet digestion procedure was repeated as an outline by Mleczek et al. [27]. Accurately weighted, $0.500( \pm 0.001) \mathrm{g}$ of dry samples were digested with $5.0 \mathrm{~mL}$ of $65 \%$ HNO3 (Merck, Darmstadt, Germany) in closed Teflon containers $(55 \mathrm{~mL})$ at $180^{\circ} \mathrm{C}$ using the microwave digestion system, Mars 6 (CEM, Matthews, NC, USA). After digestion, the samples were diluted with demineralized water to a final volume of $10 \mathrm{~mL}$.

\subsubsection{Instrumentation}

Ten elements ( $\mathrm{Al}, \mathrm{As}, \mathrm{Cd}, \mathrm{Cr}, \mathrm{Cu}, \mathrm{Fe}, \mathrm{Hg}, \mathrm{Ni}, \mathrm{Pb}$, and $\mathrm{Zn}$ ) concentration in the samples were measured. Digested samples and water extracts (samples for MARA test) were determined in parallel using inductively coupled plasma high-resolution optical emission spectrometry (ICP-HROES). A PlasmaQuant PQ 9000 Elite (Analytic Jena GmbH, Jena Germany) spectrometer was used. The standard conditions were used: Radio Frequency (RF) power $1.2 \mathrm{~kW}$, nebulizer gas flow $0.5 \mathrm{~L} \mathrm{~min}^{-1}$, plasma gas flow $12 \mathrm{~L} \mathrm{~min}^{-1}$, auxiliary gas flow $0.5 \mathrm{~L} \mathrm{~min}^{-1}$, and axial plasma view. High-resolution optics were an echelle double monochromator and charge-coupled device (HR CCD), which was cooled to $-10{ }^{\circ} \mathrm{C}$ using a Peltier system. The following analytical wavelengths (emission lines) were applied: Al 396.152 nm, As 188.979 nm, Cd 214.441 nm, Cr 267.716 nm, Cu 324.754 nm, Fe 261.187 nm, $\mathrm{Hg} 194.159 \mathrm{~nm}$, Ni $231.604 \mathrm{~nm}, \mathrm{~Pb} 220.353 \mathrm{~nm}$, and Zn $206.200 \mathrm{~nm}$. The signal was measured in 5 replicates. The sample was analyzed 3 times $(n=3)$. Argon was used as an internal standard ( $\mathrm{Ar} 420.068 \mathrm{~nm}$ ). The limits of detection (LODs, as 3-sigma criteria) were found at the level of $0.01\left(\mathrm{mg} \mathrm{kg}^{-1}\right)$ of dry weight $(w / w)$ for all elements presented. The standard addition method was used for traceability measurements. Recoveries were in the acceptable range (80-120\%). The uncertainty for the complete analytical process (including sample preparation) was at the level of $20 \%$. In the case of outliers (e.g., surprisingly high element content), the complete analytical process was repeated.

\subsection{Statistical Analysis}

Cluster analysis was performed to show either similarities or differences among the mushroom samples. According to their MTC value, the samples were clustered using the Ward method. Similarly, the samples were also clustered as regards the content of metals using the same method [12]. All statistical analyses were performed using Rstudio software version 1.3.1093.

\section{Results and Discussion}

\subsection{Microbial Toxicity Concentration}

In general, in accordance with the methodological recommendations published by Wadhia [14], the MARA assay measurements were performed on samples diluted with water. The data obtained from MARA can be expressed as the percentage of microbial growth, the percentage of relative inhibition, and microbial toxicity concentration (MTC). The result of the MARA tests is summarized in Table 2. 
Table 2. MARA test results summary.

\begin{tabular}{ccccc}
\hline Sample & Average MTC (\%) & Minimum MTC (\%) & Most Sensitive Organism & Overall Effect \\
\hline 1 & $>\max$ & 100 & - & No or very low toxicity \\
2 & 43 & 10 & No. 6 Delftia acidovorans & No or very low toxicity \\
3 & 85 & 44 & No. 7 Kurthia gibsonii & No or very low toxicity \\
4 & $>\max$ & - & No or very low toxicity \\
5 & $>\max$ & 81 & No. 6 Delftia acidovorans & No or very low toxicity \\
6 & 75 & 20 & No. 6 Delftia acidovorans & No or very low toxicity \\
\hline
\end{tabular}

In addition, MTC values for each strain are represented in Figure 4. Generally, based on the MARA result, all samples were categorized by internal system software as nontoxic or as having an extremely low toxicity.

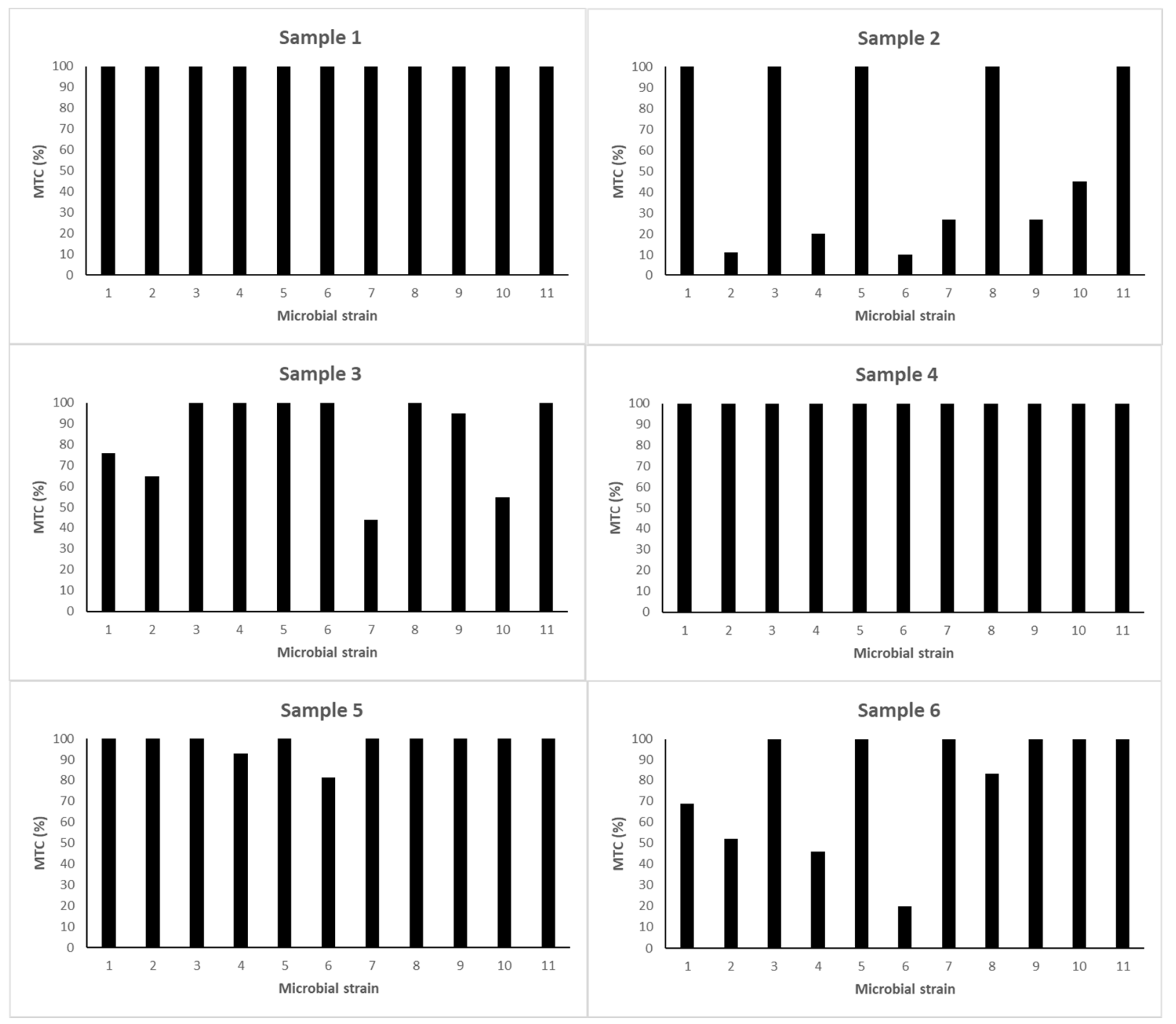

Figure 4. MTC value of six mushrooms tested for each strain, strain with y-axis $100 \%$, indicates the MTC value above maximum concentration (description of $1-11$ - see Table 1).

Samples 1 and 4 have a similar result, with the minimum MTC of both samples being $100 \%$. It indicates that the samples were extremely low toxicity. The growth of all microorganisms was not affected by inducing those samples to the wells.

Sample 2 significantly influenced the growth of microorganism nos. 2, 4, 6, 7, 9, and 10. The most sensitive microorganism was Delftia acidovoran with the lowest MTC value of 
$10 \%$, which corresponds to $10 \mathrm{mg} \mathrm{mL}^{-1}$ of mushroom extract. On average, Sample 2 had the lowest MTC values among other samples ( $43 \% 43 \mathrm{mg} \mathrm{mL}^{-1}$ of extract).

Sample 3 had an average MTC value of $85 \%$, which slowed down the growth of microorganisms no. 1, 2, 7, 9, 10. The lowest MTC value was $44 \%$, which refers to the most sensitive microorganism (Kurthia gibsonii).

Sample 5 did not interrupt almost all the microbes' growth. It very slightly reduced the pellet size in the cases of organism no. 4 (Comamonas testosteroni) and no. 6 (Delftia acidovorans) with MTC values of $93 \%$ and $81 \%$, respectively. It corresponds to at least $93 \mathrm{mg} \mathrm{mL}^{-1}$ and $81 \mathrm{mg} \mathrm{mL}^{-1}$ of mushroom concentration needed to inhibit the growth of microbes nos. 4 and 6 accordingly.

Sample 6 had no adverse effect on organisms no. 3, 5, 7, 9, 10, 11. However, it influenced the growth of organisms no. 8 (Staphylococcus warneri), no. 1 (Microbacterium species), no. 2 (Breoundimonas diminuta), no. 4 (Comamonas testosteroni) and no. 6 (Delftia acidovorans) with the decreasing value of MTC ranging from $83 \%\left(83 \mathrm{mg} \mathrm{mL}^{-1}\right)$ to $20 \%$ (20 $\mathrm{mg} \mathrm{mL}^{-1}$ ).

Mushroom toxicity is a global problem encountered in many countries. For instance, Schenk-Jaeger et al. [28] reported that there were 6307 cases caused by mushroom exposure in Switzerland. According to its report, Boletus edulis was the species with the most frequent cases (305).

Our study aimed to evaluate whether the MARA assay may be a reliable tool to determine the overall toxicity of a mushroom. For this purpose, samples of King bolete were collected in several regions and sites characterized by different risks of mushroom contamination. According to a new report by the European Environment Agency (EEA) [29], Poland is the most polluted country in Europe, and the cities of Warsaw and Łódź and their surrounding areas, in particular, see high levels of particulate pollution.

The MARA system has been developed to determine toxicity based on multi-species assay with many advantages: Cost-effectiveness, simplicity, and ease of use [12]. The test was a type of "battery of tests within a test" with an array of the 11 different growth determinations giving a consolidated toxic evaluation representing a unique sample "fingerprint" [14]. Hence, implementing the MARA assay for determining mushroom toxicity will give such advantages compared to conventional methods.

Additionally, the toxic fingerprints obtained in MARA plates were clustered in a dendrogram using Rstudio with Ward's minimum variance method. The dendrogram of the MTC value is shown in Figure 5. In general, the samples were clustered into three groups based on their similarity: Cluster 1 (Sample 3), Cluster 2 (Samples 1, 4 and 5), and Cluster 3 (Samples 2 and 6).

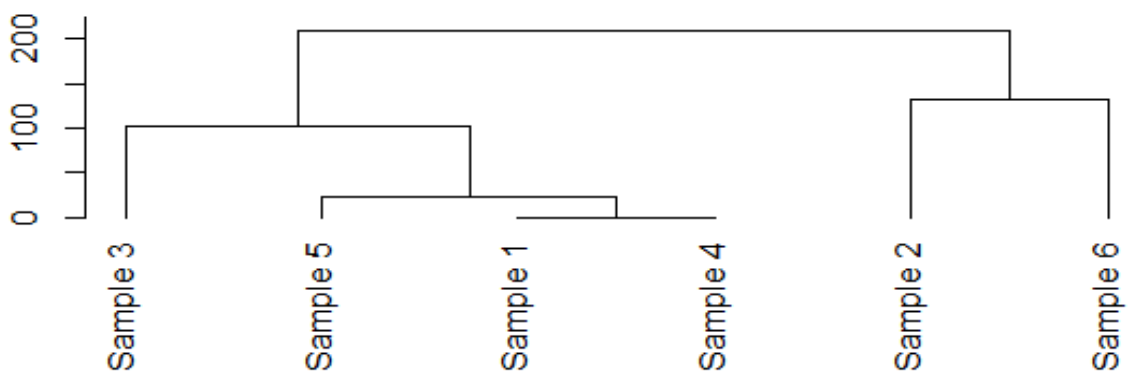

Figure 5. The dendrogram represents clustered toxic fingerprints based on the MTC values of the six mushroom samples.

Samples 1, 4 and 5 were clustered in a group based on the dendrogram in Figure 5. The most similar sample detected by the MARA test were Samples 1 and 4 since the vertical axis' height was the smallest. Both samples have the highest average MTC value among other samples, which indicates that those samples were remarkably nontoxic.

The same company collected Samples 4 and 5 at the same site near Kraków at different time frames, and they were picked in 2020 and 2019, respectively. Even though they 
were clustered together, Sample 4 collected in 2020 had slightly lower toxicity than that of Sample 5. Looking for an explanation for this, it seems reasonable to take into consideration that 2020 was the time when a pandemic struck the country, which reduced peoples' mobility. Filonchyk et al. [30] reported that the pandemic significantly improved the air quality in Poland, as indicated by reducing atmospheric pollutants by up to $23 \%$. Since tourism traffic represents one of the factors affecting ground cover quality, it cannot be excluded that samples of wild-growing mushrooms picked in 2020 were slightly less toxic than those in 2019.

Sample 1 was collected and dried individually (non-industrial) near the capital of Poland. On the contrary, Sample 2, which was also picked individually in the greater Poland province, possessed the highest toxicity among other samples. Therefore, the way of picking either performed individually or industrially had no significant effect on the toxicity since both samples were highly separated in the cluster.

Sample 6 had similarities with Sample 2 in terms of toxicity, indicating that both samples were in a single cluster. Sample 6 was collected from the Lower Silesian province, which was relatively highly contaminated, thus that the mushroom may accumulate the contamination. On the other hand, Sample 3 had medium toxicity compared to other clusters. It was picked in north Poland, which has a good air quality index [31,32].

Generally, the most sensitive microorganism in all samples was Delftia acidovorans with the MTC values of 10\% in Sample 2, 81\% in Sample 5, and 20\% in Sample 6. Even though all samples were categorized as nontoxic as the average MTC value in all samples were larger than 50\%, the samples can be clustered from the lowest to the highest toxicity; Cluster 2 (Sample 1, 4, and 5), Cluster 1 (Sample 3) and Cluster 3 (Sample 2 and 6).

\subsection{Trace Elements Content}

Samples of mushrooms were collected randomly from several regions of Poland. Both ecologically unpolluted areas with wild nature and high-risk sites potentially contaminated with toxic elements were selected as research sites for this study. Sites considered to be very contaminated in relation to soil and air are usually classified as dangerous and are often found in industrial centers. As trace elements, some heavy metals (e.g., chrome, copper, nickel) can result from several anthropogenic events [33].

The content of selected trace elements is presented in Table 3. Element content in water extracts corresponded to the response on the MARA test. However, it was markedly lower than in the dried fruit bodies of the mushrooms tested. Only $\mathrm{Al}, \mathrm{Cu}$ and $\mathrm{Zn}$ were found parallel in all digested samples and water extracts above the limit of detection (LOD). Most of the potentially toxic elements (PTEs: As, $\mathrm{Cd}, \mathrm{Hg}, \mathrm{Pb}$ ) were found below LOD $\left(<0.01 \mathrm{mg} \mathrm{kg}^{-1} \mathrm{DW}\right)$ in all samples and fractions. Ni was only detected below LOD in one water extract (Sample 1). Fe was detected in all digests but only in two water extracts (Sample 3 and 5). Cr was only detected in two acid digests.

Total contents (as mean) of the elements detected were arranged in order: $\mathrm{Cr}<\mathrm{Ni}<$ $\mathrm{Cu}<\mathrm{Zn}<\mathrm{Al}<\mathrm{Fe}$. The results varied slightly varied between the six samples. However, Sample 5 was an outlier. It contained significantly higher ( $\mathrm{Fe}, \mathrm{Al}, \mathrm{Ni}$, and $\mathrm{Cr}$ ) or lower content $(\mathrm{Cu}, \mathrm{Zn})$ than the rest of the samples. Surprisingly, high Fe and $\mathrm{Al}$ content were found, 741 and $542 \mathrm{mg} \mathrm{kg}^{-1} \mathrm{DW}$, respectively. However, repetition of the complete analytical procedure (i.e., sample preparation and measurements) confirmed these results. Therefore, significantly higher content (as a sum) of detectable elements was detected in Sample $5\left(1318 \mathrm{mg} \mathrm{kg}^{-1}\right)$ than in the rest of the samples $\left(116-384 \mathrm{mg} \mathrm{kg}^{-1} \mathrm{DW}\right)$.

In the case of water-extractable elements, only $\mathrm{Al}, \mathrm{Cu}, \mathrm{Fe}, \mathrm{Ni}$, and $\mathrm{Zn}$ were found above LODs and the results were arranged in order of significant difference: $\mathrm{Ni}<\mathrm{Al}<\mathrm{Fe}<$ $\mathrm{Cu}<\mathrm{Zn}$. Comparing all water-extractable elements, Ni was the lowest contaminant with the concentration from LOD $(<0.01)$ to $1.23 \mathrm{mg} \mathrm{kg}^{-1} \mathrm{DW}$. Al contents varied from 0.85 to $7.18 \mathrm{mg} \mathrm{kg}^{-1} \mathrm{DW}$. For essential trace elements, $\mathrm{Zn}$ had the highest concentration in almost all samples, $5.65-73.7 \mathrm{mg} \mathrm{kg}^{-1} \mathrm{DW}$. Cu content ranged from 4.02 to $15.3 \mathrm{mg} \mathrm{kg}^{-1} \mathrm{DW}$. 
In turn, Fe was only found in two water extracts, $7.18 \mathrm{mg} \mathrm{kg}^{-1} \mathrm{DW}$ (Sample 3) and $0.92 \mathrm{mg} \mathrm{kg}^{-1}$ DW (Sample 5).

Table 3. Selected trace elements content in six mushroom sample extracts $(n=3)$.

\begin{tabular}{|c|c|c|c|c|c|c|c|}
\hline \multirow{2}{*}{ Elements } & \multirow{2}{*}{ Fraction } & \multicolumn{6}{|c|}{ Samples (mg kg-1 DW) } \\
\hline & & 1 & 2 & 3 & 4 & 5 & 6 \\
\hline \multirow{3}{*}{$\mathrm{Al}$} & Total & 2.34 & 4.24 & 44.9 & 107 & 542 & 58.3 \\
\hline & Water & 1.00 & 0.85 & 3.23 & 5.28 & 7.18 & 2.14 \\
\hline & $\%$ & 43 & 20 & 7.2 & 4.9 & 1.3 & 3.7 \\
\hline \multirow{3}{*}{$\mathrm{Cr}$} & Total & $<0.01$ & $<0.01$ & $<0.01$ & 0.01 & 0.05 & $<0.01$ \\
\hline & Water & $<0.01$ & $<0.01$ & $<0.01$ & $<0.01$ & $<0.01$ & $<0.01$ \\
\hline & $\%$ & - & - & - & - & - & - \\
\hline \multirow{3}{*}{$\mathrm{Cu}$} & Total & 26.0 & 36.3 & 15.7 & 9.37 & 9.92 & 11.7 \\
\hline & Water & 5.41 & 8.34 & 15.3 & 4.63 & 4.02 & 3.47 \\
\hline & $\%$ & 21 & 23 & 97 & 49 & 41 & 30 \\
\hline \multirow{3}{*}{$\mathrm{Fe}$} & Total & 10.9 & 16.0 & 55.7 & 106 & 741 & 98.6 \\
\hline & Water & $<0.01$ & $<0.01$ & 7.18 & $<0.01$ & 0.92 & $<0.01$ \\
\hline & $\%$ & - & - & 13 & - & 0.1 & - \\
\hline \multirow{3}{*}{$\mathrm{Ni}$} & Total & 0.39 & 0.98 & 1.74 & 0.61 & 1.12 & 0.43 \\
\hline & Water & $<0.01$ & 0.20 & 1.23 & 0.23 & 0.23 & 0.24 \\
\hline & $\%$ & - & 21 & 70 & 38 & 20 & 56 \\
\hline \multirow{3}{*}{$\mathrm{Zn}$} & Total & 76.8 & 83.2 & 91.4 & 46.5 & 23.6 & 78.7 \\
\hline & Water & 16.0 & 5.65 & 73.7 & 8.54 & 12.9 & 21.4 \\
\hline & $\%$ & 21 & 6.8 & 81 & 18 & 55 & 27 \\
\hline
\end{tabular}

$<0.01$-below the limit of detection; DW—dry weight; Total—element content in acid digests; Water-element content in water extracts, \%-water-extractable percentage of total element content.

Moreover, extractable elements were calculated as a percentage of total concentration, and the following series was observed: $\mathrm{Fe}<\mathrm{Al}<\mathrm{Ni}<\mathrm{Zn}<\mathrm{Cu}$. Water-extractable percentages of total element contents were in the following ranges: $\mathrm{Fe}(0.1-13 \%), \mathrm{Al}(1.3-43 \%), \mathrm{Ni}$ $(20-71 \%), \mathrm{Zn}(6.8-81 \%)$, and $\mathrm{Cu}(21-97 \%)$ It is worth noting that Sample 3 contained the highest extractable percentage of $\mathrm{Cu}(97 \%), \mathrm{Ni}(70 \%), \mathrm{Zn}(81 \%)$, and Fe (13\%). Therefore, a significantly higher content (as a sum) of extractable elements was detected in Sample 3 (101 $\mathrm{mg} \mathrm{kg}^{-1}$, which corresponded to $48 \%$ of total content) than in the rest of the samples (15.0-27.2 $\left.\mathrm{mg} \mathrm{kg}^{-1}\right)$.

In comparison to a half-century monitoring study of wild-growing mushrooms, the contents of all detected elements were in similar ranges, except $\mathrm{Cu}$, which was slightly higher [27]. In contrast to these authors' findings, most of the potentially toxic elements (PTEs) were found below LODs (As, $\mathrm{Cd}, \mathrm{Hg}, \mathrm{Pb}$ ) or in lower concentrations than reported $(\mathrm{Al}, \mathrm{Cr}, \mathrm{Ni})$. Moreover, the samples were slightly less contaminated with PTEs in comparison to those found by Mleczek et al. [27]. Zhang et al. [34] reported a lower concentration of $\mathrm{Al}, \mathrm{Cu}, \mathrm{Fe}$, and $\mathrm{Zn}$ in the caps and stipes of Boletus edulis, while As, $\mathrm{Cd}, \mathrm{Hg}$, and $\mathrm{Pb}$ were found in higher concentrations. However, Sample 5 was an outlier with Fe and Al contents surprisingly high. According to Falandysz et al. [35], Al is highly bio-excluded by King Bolete, although Gaso et al. [36] even determined $1200 \mathrm{mg} \mathrm{kg}^{-1}$ DW in Boletus edulis. In the case of Fe content, it was reported that other mushroom species found Fe better than Boletus edulis [35] and the highest reported Fe content was $340 \mathrm{mg} \mathrm{kg}^{-1}$ DW [36]. Nevertheless, in the case of purchased mushrooms, it is impossible to clearly indicate the cause of this surprising bioaccumulation.

Furthermore, clustering analysis was performed based on the element contents in dried samples (Figure 6a) and water extracts (Figure 6b). Based on the provided dendrogram in Figure 6, the outliers were Sample 5 in the dried sample and Sample 3 in water extracts because they had the highest concentration in all detected metals. The samples with the lowest element concentrations were clustered together, i.e., samples no. 1 and 2 
in the dried samples and no. 2, 4, and 5 in water extracts. In general, the dendrograms show a different pattern, which indicates that the relation of elements contents in dried samples and in water extracts varies from one sample to another. The differences were mainly due to the variation in the extraction coefficient of each sample. The content of water-extractable elements ranged from 1.9\% (Sample 5) to $48 \%$ (Sample 3) of the total content of these elements in the dry samples. However, the Euclidian distance in Figure $6 \mathrm{a}, \mathrm{b}$ ranged 0-1000 and 0-100 in the dendrograms, respectively. This value represents that the average extractable elements from dried samples to the solvent was roughly $10 \%$.

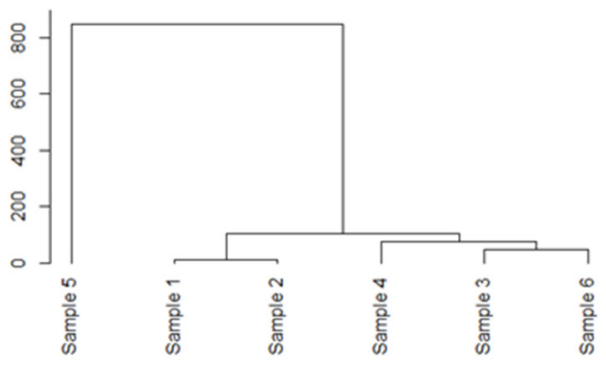

(a)

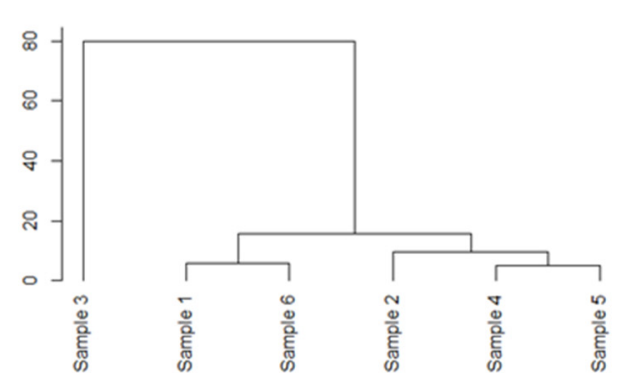

(b)

Figure 6. Dendrogram representing clustered toxic fingerprint based on heavy metal content of the six mushroom samples: In (a) dried samples and (b) water extracts.

\subsection{Mushroom Intake and Its Risk to Human}

The European Food Safety Authority (EFSA) sets a tolerable weekly intake (TWI) for $\mathrm{Al}$ as $1 \mathrm{mg} \mathrm{kg}^{-1}$ of body weight (BW) for all groups of people. For an individual with a bodyweight of $65 \mathrm{~kg}$, the value is $9.29 \mathrm{mg} \mathrm{day}^{-1}$ [37]. At the same time, the Institute of Medicine Food and Nutrition Board sets a tolerable upper intake level (UL), which is the maximum daily intake that poses no health risk. The UL value of $\mathrm{Cu}, \mathrm{Fe}, \mathrm{Ni}$, and $\mathrm{Zn}$ are $10 \mathrm{mg} \mathrm{day}^{-1}, 45 \mathrm{mg} \mathrm{day}^{-1}, 1 \mathrm{mg} \mathrm{day}^{-1}$, and $40 \mathrm{mg} \mathrm{day}^{-1}$, respectively. However, the UL was not established for $\mathrm{Cr}$ [38]. The World Health Organization (WHO) suggested that supplemental intake of chromium should not exceed $0.250 \mathrm{mg} \mathrm{day}^{-1}$ [39].

According to the trace elements concentration in each sample that was examined in this study, an attempt to calculate the total maximum daily intake $(\mathrm{kg})$ was taken, and the limiting factor was its lowest value (Table 4). Due to results obtained, the minimum mushroom consumption, which could cause adverse effects varied from 0.02 to $0.38 \mathrm{~kg} \mathrm{day}^{-1}$. $\mathrm{Cu}$ content was a limiting factor for total maximum daily intake for samples collected and picked individually (Samples 1, 2). In turn, Al content was a limiting factor in Samples 3-6, which were purchased on the market from local producers (offering packaging between 20 and $30 \mathrm{~g}$ ). According to this, by consuming a single portion (20-30 g) of Sample 5, the maximum daily intake could be exceeded. Presumably, different limiting factors for these groups of samples may result from different picking or drying techniques. In consequence, total maximum daily intake was significantly different for Samples 1, $2(0.28-0.38 \mathrm{~kg})$ and Samples 3-6 (0.02-0.21 kg).

Generally, a single mushroom portion (20-30 g) could not pose any health issue in accordance with the Tolerable Upper Intake Level (UL). Since Sample 5, which was collected near one of the industrial centers, became an outlier, a potential health risk might be caused in this case by consuming $20 \mathrm{~g}$ of mushrooms. Although this value was relatively lower than the average mushroom consumption per capita globally (13 $\mathrm{g} \mathrm{day}^{-1}$ ) [40]. Therefore, $20 \mathrm{~g}$ daily is still considered as low toxicity, aligning with the result from the MARA assay. Compared to the rest, Samples 4 and 5 (collected near Kraków by the same company) contained less $\mathrm{Zn}$ and $\mathrm{Cu}$ while also containing more $\mathrm{Al}, \mathrm{Cr}$, and $\mathrm{Fe}$. Moreover, the daily consumption of Samples 4 and 5 should not exceed 0.09 and $0.02 \mathrm{~kg}$, respectively. In Samples 1-3 and 6, consuming $100 \mathrm{~g}$ mushrooms could not pose any health issue, which corresponded to 4-5 portions (20-30 g) purchased on the market from local producers. 
Table 4. Maximum daily intake of the six mushroom samples.

\begin{tabular}{cccccccc}
\hline \multirow{2}{*}{ Elements } & \multirow{2}{*}{$\begin{array}{c}\text { UL } \\
\text { (mg day }\end{array}$} & \multicolumn{7}{c}{ Sample $\mathbf{~ ( k g ) ~}$} \\
\cline { 3 - 8 } & & $\mathbf{1}$ & $\mathbf{2}$ & $\mathbf{3}$ & $\mathbf{4}$ & $\mathbf{5}$ & $\mathbf{6}$ \\
\hline $\mathrm{Al}$ & $9.29[37]$ & 3.97 & 2.19 & 0.21 & 0.09 & 0.02 & 0.16 \\
$\mathrm{Cr}$ & $0.25[39]$ & $\mathrm{N} / \mathrm{A}$ & $\mathrm{N} / \mathrm{A}$ & $\mathrm{N} / \mathrm{A}$ & 25.0 & 5.00 & $\mathrm{~N} / \mathrm{A}$ \\
$\mathrm{Cu}$ & $10.0[38]$ & 0.38 & 0.28 & 0.64 & 1.07 & 1.01 & 0.85 \\
$\mathrm{Fe}$ & $45.0[38]$ & 4.13 & 2.81 & 0.81 & 0.42 & 0.06 & 0.46 \\
$\mathrm{Ni}$ & $1.00[38]$ & $\mathrm{N} / \mathrm{A}$ & 1.02 & 0.57 & 1.64 & 0.89 & 2.33 \\
$\mathrm{Zn}$ & $40.0[38]$ & 0.52 & 0.48 & 0.44 & 0.86 & 1.69 & 0.51 \\
\hline Total maximum & & 0.38 & 0.28 & 0.21 & 0.09 & 0.02 & 0.16 \\
daily intake $(\mathrm{kg})$ & & & & & & & \\
\hline
\end{tabular}

UL: The Tolerable Upper Intake Level is the highest level of daily nutrient intake that is likely to pose no risk of adverse health effects for almost all individuals.

\section{Conclusions}

The MARA obtained from this preliminary study established that all the samples of wild-growing King bolete mushrooms that were examined had no or very low toxicity. Generally, the measurements of element content using ICP-HROES confirmed that the samples do not contain any potentially toxic elements (PTEs). In addition, the analysis of digested samples proved that the element content in water extracts was markedly lower than in dried fruit bodies. The result presented in this study provides an appropriate starting point to identify a reliable approach to toxicity determination in some other biobased and food-related raw materials.

Author Contributions: Conceptualization, P.K.; methodology, M.A.Z., P.K., J.P., and Ł.T.; software, M.A.Z., J.P., and Ł.T.; validation, P.K., J.P., and Ł.T.; formal analysis, J.P. and Ł.T.; writing —original draft preparation, M.A.Z., P.K., and J.P.; writing-review and editing, M.A.Z., P.K., J.P., and Ł.T.; visualization, J.P. and M.A.Z.; supervision, P.K.; project administration, P.K. and Ł.T.; funding acquisition, P.K. and J.P. All authors have read and agreed to the published version of the manuscript.

Funding: This research was funded by the European Union through the European Social Fund under the Operational Program Knowledge Education Development grant No. POWR.03.02.00-00-I026/16.

Institutional Review Board Statement: Not applicable.

Informed Consent Statement: Not applicable.

Data Availability Statement: Not applicable.

Conflicts of Interest: The authors declare no conflict of interest.

\section{References}

1. Širić, I.; Falandysz, J. Contamination, bioconcentration and distribution of mercury in Tricholoma spp. mushrooms from southern and northern regions of Europe. Chemosphere 2020, 251, 126614. [CrossRef] [PubMed]

2. Mleczek, M.; Niedzielski, P.; Kalač, P.; Budka, A.; Siwulski, M.; Gasecka, M.; Rzymski, P.; Magdziak, Z.; Sobieralski, K. Multielemental analysis of 20 mushroom species growing near a heavily trafficked road in Poland. Environ. Sci. Pollut. Res. 2016, 23, 16280-16295. [CrossRef]

3. Rudawska, M.; Leski, T. Macro- and microelement contents in fruiting bodies of wild mushrooms from the Notecka forest in west-central Poland. Food Chem. 2005, 92, 499-506. [CrossRef]

4. Nieminen, P.; Mustonen, A.-M. Toxic Potential of Traditionally Consumed Mushroom Species-A Controversial Continuum with Many Unanswered Questions. Toxins 2020, 12, 639. [CrossRef]

5. Cocchi, L.; Vescovi, L.; Petrini, L.E.; Petrini, O. Heavy metals in edible mushrooms in Italy. Food Chem. 2006, 98, 277-284. [CrossRef]

6. Falandysz, J.J.; Kunito, T.; Kubota, R.; Bielawski, L.; Frankowska, A.; Tanabe, S. Multivariate characterization of elements accumulated in King BoleteBoletus edulismushroom at lowland and high mountain regions. J. Environ. Sci. Health Part A 2008, 43, 1692-1699. [CrossRef]

7. García, M.A.; Alonso, J.; Melgar, M.J. Lead in edible mushroomsLevels and bioaccumulation factors. J. Hazard. Mater. 2009, 167, 777-783. [CrossRef] 
8. Commission, R. (EC) No. 629/2008 of 2 July 2008 amending Regulation (EC) No. 1881/2006 setting maximum levels for certain contaminants in foodstuffs. Off. J. Eur. Union 2008, 173, 6-9.

9. Lyubenova, M.; Boteva, S. Biotests in Ecotoxicology: Current Practice and Problems. In Toxicology-New Aspects to This Scientific Conundrum; IntechOpen: London, UK, 2016.

10. Wolska, L.; Sagajdakow, A.; Kuczyńska, A.; Namieśnik, J. Application of ecotoxicological studies in integrated environmental monitoring: Possibilities and problems. TrAC Trends Anal. Chem. 2007, 26, 332-344. [CrossRef]

11. Markwiese, J.T.; Ryti, R.T.; Hooten, M.M.; Michael, D.I.; Hlohowskyj, I. Toxicity bioassays for ecological risk assessment in arid and semiarid ecosystems. Residue Rev. 2001, 168, 43-98.

12. Gabrielson, J.; Kühn, I.; Colque-Navarro, P.; Hart, M.; Iversen, A.; McKenzie, D.; Möllby, R. Microplate-based microbial assay for risk assessment and (eco)toxic fingerprinting of chemicals. Anal. Chim. Acta 2003, 485, 121-130. [CrossRef]

13. Sieroslawska, A. Evaluation of usefulness of Microbial Assay for Risk Assessment (MARA) in the cyanobacterial toxicity estimation. Environ. Monit. Assess. 2014, 186, 4629-4636. [CrossRef]

14. Wadhia, K.; Dando, T.; Thompson, K.C. Intra-laboratory evaluation of Microbial Assay for Risk Assessment (MARA) for potential application in the implementation of the Water Framework Directive (WFD). J. Environ. Monit. 2007, 9, 953-958. [CrossRef]

15. Bronowska, M.; Bystrzejewska-Piotrowska, G.; Sterebowski, R. Estimation of the acute cesium toxicity by the microbial assay for risk assessment (MARA) test. Nukleonika 2013, 58, 481-485.

16. Nałęcz-Jawecki, G.; Wadhia, K.; Adomas, B.; Piotrowicz-Cieślak, A.; Sawicki, J. Application of microbial assay for risk assessment biotest in evaluation of toxicity of human and veterinary antibiotics. Environ. Toxicol. 2010, 25, 487-494. [CrossRef]

17. Percival, S.L.; Williams, D.W. Chapter Nine-Mycobacterium. In Microbiology of Waterborne Diseases, 2nd ed.; Percival, S.L., Yates, M.V., Williams, D.W., Chalmers, R.M., Gray, N.F., Eds.; Academic Press: London, UK, 2014; pp. $177-207$.

18. Ryan, M.P.; Pembroke, J.T. Brevundimonas spp: Emerging global opportunistic pathogens. Virulence 2018, 9, 480-493. [CrossRef]

19. Lalaoui, R.; Djukovic, A.; Bakour, S.; Hadjadj, L.; Sanz, J.; Salavert, M.; López-Hontangas, J.L.; Sanz, M.A.; Ubeda, C.; Rolain, J.-M. Genomic characterization of Citrobacter freundii strains coproducing OXA-48 and VIM-1 carbapenemase enzymes isolated in leukemic patient in Spain. Antimicrob. Resist. Infect. Control. 2019, 8, 167. [CrossRef] [PubMed]

20. Bayhan, G.I.; Tanir, G.; Karaman, I.; Ozkan, S. Comamonas testosteroni: An Unusual Bacteria Associated with Acute Appendicitis. Balk. Med. J. 2013, 30, 447-448. [CrossRef] [PubMed]

21. Giraffa, G. Lactic Acid Bacteria: Enterococcus in Milk and Dairy Products. In Reference Module in Food Science; Elsevier: Amsterdam, The Netherlands, 2020.

22. Mahmood, S.; Taylor, K.E.; Overman, T.L.; McCormick, M.I. Acute infective endocarditis caused by Delftia acidovorans, a rare pathogen complicating intravenous drug use. J. Clin. Microbiol. 2012, 50, 3799-3800. [CrossRef] [PubMed]

23. Abdul-Mutalib, N.-A.; Nordin, S.A.; Osman, M.; Ishida, N.; Tashiro, K.; Sakai, K.; Tashiro, Y.; Maeda, T.; Shirai, Y. Pyrosequencing analysis of microbial community and food-borne bacteria on restaurant cutting boards collected in Seri Kembangan, Malaysia, and their correlation with grades of food premises. Int. J. Food Microbiol. 2015, 200, 57-65. [CrossRef]

24. Kini, G.D.; Patel, K.; Parris, A.R.; Tang, J.S. An Unusual Presentation of Endocarditis Caused by Staphylococcus warneri. Open Microbiol. J. 2010, 4, 103-105. [CrossRef] [PubMed]

25. Rovera, M.; Pastor, N.; Niederhauser, M.; Rosas, S.B. Evaluation ofPseudomonas chlororaphissubsp.aurantiacaSR1 for growth promotion of soybean and for control ofMacrophomina phaseolina. Biocontrol Sci. Technol. 2014, 24, 1012-1025. [CrossRef]

26. Karkey, A.; Joshi, N.; Chalise, S.; Joshi, S.; Shrestha, S.; Nguyen, T.N.T.; Dongol, S.; Basnyat, B.; Baker, S.; Boinett, C.J. Outbreaks of Serratia marcescens and Serratia rubidaea bacteremia in a central Kathmandu hospital following the 2015 earthquakes. Trans. $R$. Soc. Trop. Med. Hyg. 2018, 112, 467-472. [CrossRef] [PubMed]

27. Mleczek, M.; Siwulski, M.; Budka, A.; Mleczek, P.; Budzyńska, S.; Szostek, M.; Kuczyńska-Kippen, N.; Kalač, P.; Niedzielski, P.; Gasecka, M.; et al. Toxicological risks and nutritional value of wild edible mushroom species -a half-century monitoring study. Chemosphere 2021, 263, 128095. [CrossRef] [PubMed]

28. Schenk-Jaeger, K.M.; Rauber-Lüthy, C.; Bodmer, M.; Kupferschmidt, H.; Kullak-Ublick, G.A.; Ceschi, A. Mushroom poisoning: A study on circumstances of exposure and patterns of toxicity. Eur. J. Intern. Med. 2012, 23, e85-e91. [CrossRef]

29. European Environment Agency. Air Quality in Europe-2020 Report; Publications Office of the European Union: Luxembourg, 2020.

30. Filonchyk, M.; Hurynovich, V.; Yan, H. Impact of Covid-19 lockdown on air quality in the Poland, Eastern Europe. Environ. Res. 2020, 110454. [CrossRef]

31. Brzezicha-Cirocka, J.; Mędyk, M.; Falandysz, J.; Szefer, P. Bio- and toxic elements in edible wild mushrooms from two regions of potentially different environmental conditions in eastern Poland. Environ. Sci. Pollut. Res. 2016, 23, 21517-21522. [CrossRef]

32. Falandysz, J.; Jędrusiak, A.; Lipka, K.; Kannan, K.; Kawano, M.; Gucia, M.; Brzostowski, A.; Dadej, M. Mercury in wild mushrooms and underlying soil substrate from Koszalin, North-central Poland. Chemosphere 2004, 54, 461-466. [CrossRef]

33. Ferrante, M.; Maria, F.; Copat, C.; Morina, S.; Caterina, L.; Mauceri, C.; Gea Oliveri, C. Air Pollution in High-Risk Sites-Risk Analysis and Health Impact; IntechOpen: London, UK, 2015.

34. Zhang, D.; Frankowska, A.; Jarzyska, G.; Kojta, A.; Drewnowska, M.; Wydmaska, D.; Bielawski, L.; Wang, J.; Falandysz, J. Metals of King Bolete (Boletus edulis) Bull.: Fr. collected at the same site over two years. Afr. J. Agric. Res. 2010, 5, 3050-3055. [CrossRef]

35. Falandysz, J.; Frankowska, A.; Jarzyńska, G.; Dryżałowska, A.; Kojta, A.K.; Zhang, D. Survey on composition and bioconcentration potential of 12 metallic elements in King Bolete (Boletus edulis) mushroom that emerged at 11 spatially distant sites. J. Environ. Sci. Health Part B 2011, 46, 231-246. [CrossRef] 
36. Gaso, M.; Segovia, N.; Morton, O.; Cervantes, M.; Godinez, L.; Peña, P.; Acosta, E. 137Cs and relationships with major and trace elements in edible mushrooms from Mexico. Sci. Total. Environ. 2000, 262, 73-89. [CrossRef]

37. Stahl, T.; Falk, S.; Rohrbeck, A.; Georgii, S.; Herzog, C.; Wiegand, A.; Hotz, S.; Boschek, B.; Zorn, H.; Brunn, H. Migration of aluminum from food contact materials to food-A health risk for consumers? Part I of III: Exposure to aluminum, release of aluminum, tolerable weekly intake (TWI), toxicological effects of aluminum, study design, and methods. Environ. Sci. Eur. 2017, 29, 1-8. [CrossRef] [PubMed]

38. Institute of Medicine Food and Nutrition Board. Dietary Reference Intakes for Vitamin A, Vitamin K, Arsenic, Boron, Chromium, Copper, Iodine, Iron, Manganese, Molybdenum, Nickel, Silicon, Vanadium, and Zinc. J. Am. Diet. Assoc. 2001, 101, $294-301$.

39. World Health Organization. Trace Elements in Human Nutrition and Health (A Report of a Re-Evaluation of the Role of Trace Elements in Human Health and Nutrition); World Health Organization: Geneva, Switzerland, 1996.

40. Royse, D.J.; Baars, J.; Tan, Q. Current Overview of Mushroom Production in the World. In Edible and Medicinal Mushrooms: Technology and Applications; Zied, D.C., Pardo-Giménez, A., Eds.; Wiley-Blackwell: Hoboken, NJ, USA, 2017; pp. 5-13. [CrossRef] 